\title{
Complete regression of multiple biventricular thrombi in dilated cardiomyopathy: the role of cardiovascular magnetic resonance imaging for diagnosis and assessing treatment response
}

\author{
Marta Fonseca (1) , ${ }^{1}$ Konstantinos Savvatis, ${ }^{1}$ Mohammed Khanji (1) 1,2,3
}

'Department of Cardiology, Barts Heart Centre, St Bartholomew's Hospital, London, UK

${ }^{2}$ Department of Cardiology, Newham University Hospital, Barts Health NHS Trust, London, UK

${ }^{3} \mathrm{NIHR}$ Barts Biomedical

Research Centre, William Harvey Research Institute, Queen Mary University of London, London, UK

Correspondence to Dr Mohammed Khanji; m.khanji@qmul.ac.uk

Accepted 23 March 2021
Check for updates

(c) BMJ Publishing Group Limited 2021. No commercial re-use. See rights and permissions. Published by BMJ.

\begin{tabular}{|l|}
\hline To cite: Fonseca M, \\
Savvatis K, Khanji M. BMJ \\
Case Rep 2021;14:e241621. \\
doi:10.1136/bcr-2021- \\
241621 \\
\hline
\end{tabular}

\section{DESCRIPTION}

A 40-year-old man presented with a 7-day history of progressive breathlessness, orthopnoea and peripheral oedema. He had a history of excess alcohol intake, cannabis use and learning difficulties. The electrocardiogram revealed left bundle branch block (figure 1A).

Transthoracic echocardiography revealed severely impaired biventricular function associated with a 'cystic' left ventricular mass (figure 1B). There was no evidence of pulmonary or systemic embolism. Warfarin was initiated for suspected thrombus with bridging low molecular-weight heparin.

Cardiovascular magnetic resonance (CMR) imaging to assess heart failure aetiology showed
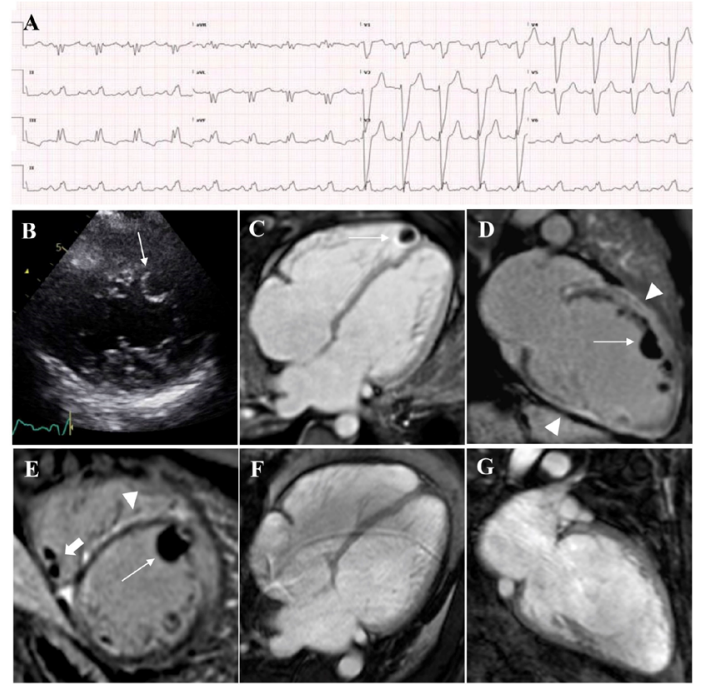

Figure 1 (A) The 12-lead ECG showing sinus rhythm with complete left bundle branch block; (B) transthoracic echocardiography parasternal short axis view, depicting a 'cystic' left ventricular mass (arrow); (C) four-chamber long axis image of cardiovascular magnetic resonance (CMR) with early gadolinium enhancement (EGE) demonstrating a round right ventricular apical thrombus (arrow); ( $D$ and $E$ ) two-chamber long axis and mid short axis CMR images with late gadolinium enhancement showing multiple thrombi adjacent to the anterior left ventricular wall (arrow) and right ventricular free wall (small arrow); there is also extensive subepicardial late gadolinium enhancement (arrowheads); ( $F$ and $G$ ) fourchamber and two-chamber long axis CMR images with EGE showing complete resolution of biventricular thrombi after 1 year.

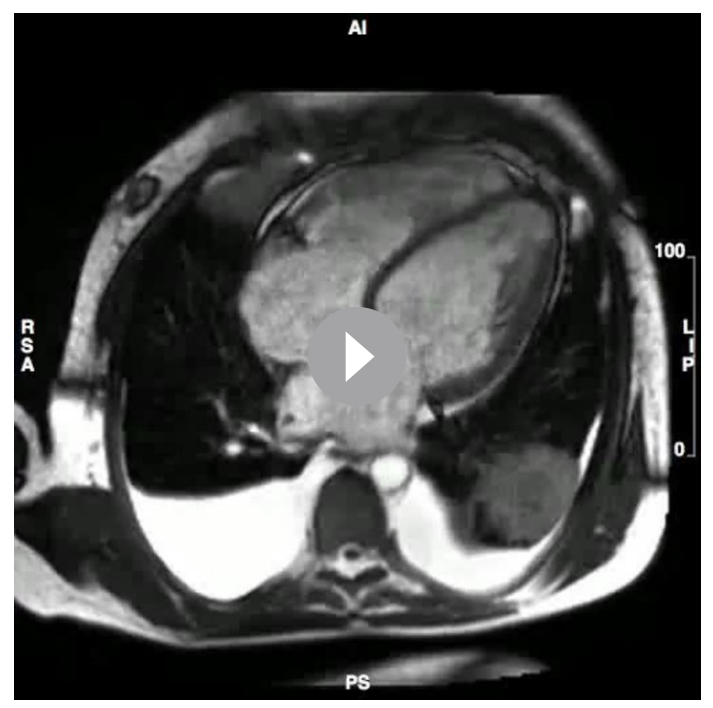

Video 1 Cardiovascular magnetic resonance fourchamber long axis cine

severe biventricular dilatation and dysfunction (ejection fraction approximately 20\%) with hypertrabeculation in the range of non-compactation (video 1). Early and late gadolinium imaging confirmed the presence of multiple left ventricular thrombi as well as right ventricular thrombi and extensive subepicardial late gadolinium enhancement (figure 1C-E).

The patient was discharged on warfarin and guideline-based heart failure medication. After 8 months of poor international normalised ratio (INR) control due to erratic compliance, off-label rivaroxaban was initiated. Repeat CMR after a year showed complete resolution of the thrombi despite persistent severe left ventricular dysfunction (figure $1 F, G$ ).

\section{Learning points}

- The occurrence of biventricular thrombi in the setting of dilated cardiomyopathy is rare.

- The detection of apical left ventricular thrombi and right ventricular thrombi might be difficult using echocardiography.

- Cardiovascular magnetic resonance is key for making a correct diagnosis and guiding management, especially in the context of offlabel use of direct oral anticoagulants. 
The occurrence of multiple biventricular thrombi in the setting of dilated cardiomyopathy is rare and the reported cases are usually associated with other risk factors-hypertrabeculation associated with dilated cardiomyopathy in this patient. CMR is the gold standard for tissue characterisation. In this case, it identified not only one, but multiple biventricular masses. Early and late gadolinium enhancement confirmed they were thrombi. CMR was, therefore, key for diagnosis, guiding management and monitoring of therapeutic efficacy.

Contributors MK was responsible for the conception and design of the work. MF was directly involved in patient imaging and was responsible for collecting the data and drafting the manuscript. KS was directly involved in the care of the patient. Both MK and KS revised the final version of the manuscript that was approved by all authors.

Funding The authors have not declared a specific grant for this research from any funding agency in the public, commercial or not-for-profit sectors.

Competing interests None declared.

Patient consent for publication Obtained.

Provenance and peer review Not commissioned; externally peer-reviewed.

\section{ORCID iDs}

Marta Fonseca http://orcid.org/0000-0002-7656-0237

Mohammed Khanji http://orcid.org/0000-0002-5903-4454

Copyright 2021 BMJ Publishing Group. All rights reserved. For permission to reuse any of this content visit https://www.bmj.com/company/products-services/rights-and-licensing/permissions/

BMJ Case Report Fellows may re-use this article for personal use and teaching without any further permission.

Become a Fellow of BMJ Case Reports today and you can:

- Submit as many cases as you like

- Enjoy fast sympathetic peer review and rapid publication of accepted articles

Access all the published articles

Re-use any of the published material for personal use and teaching without further permission

Customer Service

If you have any further queries about your subscription, please contact our customer services team on +44 (0) 2071111105 or via email at support@bmj.com.

Visit casereports.bmj.com for more articles like this and to become a Fellow 